\title{
Understanding Motives of Indigenous Cattle Farmers Joining Farmers Group in Brebes Regency, Indonesia
}

\author{
Mochamad Sugiarto ${ }^{1 *}$, Yusmi Nur Wakhidati ${ }^{1}$, Oentoeng Edy Djatmiko ${ }^{1}$, Syarifuddin Nur ${ }^{1}$ and Dyah \\ Gandasari $^{2}$
}

\author{
${ }^{1}$ Faculty of Animal Science, Jenderal Soedirman University, Purwokerto, Indonesia, 53123 \\ 2Bogor Agriculture Development Polytechnic (POLBANGTAN Bogor), Human Resource Development and Extension \\ Agency, Ministry of Agriculture, Bogor, Indonesia 16730 \\ *Corresponding author email: mochamad.sugiarto@unsoed.ac.id
}

\begin{abstract}
The development of Jawa Brebes (Jabres) cattle as indigenous cattle in Brebes Regency, Indonesia, is carried out using a farmer group approach. Cattle farmers join farmer groups with various motives and purposes. Understanding the motives of indigenous cattle farmers joining farmers group in Brebes Regency, Indonesia, this study aimed to identify the motives of Jabres cattle farmers to join the group and analyze the influencing factors of different motives to join farmers group. The study used a survey method to 119 Jabres cattle farmers in Brebes Regency. Respondents were selected using multistage sampling. Data were analyzed using descriptive statistics to depict the cattle farmers' characteristics and identify their motives to join the farmers' group. Discriminant analysis identified the influencing factors of Jabres cattle farmers' different reasons for joining the Jabres cattle farmers group. The majority of the Jabres cattle farmers in Brebes Regency (75.6 percent) entered the farmers' group due to social motive and expectancy to feel secure in social interactions with other farmers. Farmer's education is an essential factor that causes differences in cattle farmers' motives in joining farmer groups $(\mathrm{P}<0.05)$. Cattle farmers with higher education join the farmers' group to gain additional knowledge and realize beef cattle business goals (profitability and marketing).
\end{abstract}

Keywords: motives, farmers' group, farmers' education

Abstrak. Pengembangan sapi Jawa Brebes (Jabres) sebagai sapi lokal di Kabupaten Brebes, Indonesia, dilakukan dengan pendekatan kelompok peternak. Peternak sapi Jabres tergabung dalam kelompok peternak dengan berbagai motif dan tujuan. Kajian tentang pemahaman motif peternak sapi Jabres untuk bergabung dengan kelompok peternak di Kabupaten Brebes, Indonesia, bertujuan untuk mengetahui motif peternak sapi Jabres bergabung dalam kelompok dan menganalisis faktor-faktor yang mempengaruhi perbedaan motif peternak sapi dalam bergabung dengan kelompok peternak. Penelitian menggunakan metode survei pada 119 peternak sapi Jabres di Kabupaten Brebes. Responden dipilih menggunakan multistage sampling. Analisis data menggunakan statistik deskriptif untuk menggambarkan karakteristik peternak sapi Jabres dan mengidentifikasi motif peternak bergabung dalam kelompok peternak. Analisis diskriminan digunakan untuk mengetahui faktor-faktor yang mempengaruhi perbedaan motif peternak sapi Jabres bergabung dalam kelompok peternak sapi Jabres. Sebagian besar peternak sapi Jabres di Kabupaten Brebes (75,6 persen) bergabung ke dalam kelompok peternak karena motif sosial yaitu mengharapkan merasa aman melalui interaksi sosial dengan peternak lainnya. Pendidikan peternak merupakan faktor penting yang menyebabkan perbedaan motif peternak sapi dalam bergabung ke kelompok peternak $(P<0,05)$. Peternak sapi dengan pendidikan tinggi bergabung dalam kelompok peternak sapi Jabres untuk menambah pengetahuan dan mewujudkan tujuan bisnis sapi potong (profitabilitas dan pemasaran).

Kata kunci: motif, kelompok peternak, pendidikan petani

\section{Introduction}

Rural development in Brebes Regency cannot be separated from livestock development, which is always expected to bring about social and economic changes. The presence of Jawa Brebes (Jabres) cattle as local cattle in Brebes Regency is important news that is continuously followed up as an economic activity to increase its welfare. In developing countries, cattle have social, economic, and cultural functions for rural communities (Bettencourt et al., 2015). Until 2019, Jabres cattle has reached a population of 27,000 heads and been able to reduce rural unemployment. Jabres cattle tend to be managed by rural communities in the highland areas of Brebes Regency such as Ketanggungan, 
Bantarkawung, Banjarharjo, Larangan, and Salem Districts. The presence of Jabres cattle in rural areas is believed to increase family income and control unemployment. Livestock, in general, is an economic activity that provides additional income for rural communities and absorbs rural labor (Herrero et al., 2013). Specifically, livestock business can make differences in the welfare of rural communities compared to community groups that do not carry out livestock production (Truong et al., 2020)

The farmers group is present as a group of Jabres cattle farmers from various backgrounds to achieve common goals. The foundation of human life and social interaction is the existence of groups. Groups of individuals create a group to synchronize their activities in achieving goals that cannot be completed individually (Hogg et al., 2009). Farmer groups have an important role in planning to increase livestock productivity, financial management, and developing beef cattle businesses. Group members try to improve their knowledge, skills, and attitudes by seeking information related to the application of technology (Abdullah et al., 2019). The existence of Jabres cattle farmers group has supported the increasing population of Jabres cattle in Brebes Regency. Farmers have exchanged information and knowledge within and between groups to increase Jabres cattle production. Farmers with different backgrounds unite and integrate into the Jabres cattle farmer group to realize changes in their economic development. However, farmers can attend and join the farmers group with different objectives. Farmers motives contribute to their decision-making process to join the group. Group development decisions need to pay attention to individual motives and behavior. There is now a growing interest in understanding the motives underlying actors decision to rural development, such as farmers in strengthening groups (Hansson et al., 2013).

Group sustainability is a strategic and important issue in ensuring an increased population of beef cattle in Jawa Brebes (Jabres). Jabres cattle development is carried out primarily using a farmers group approach. Until 2020 , there were 40 Jabres cattle farmers groups in the center area of Jabres cattle development in Brebes Regency. The group existence is highly colored by the motives and goals of each member to be part of the group. Jabres cattle business uncertainty will be suppressed and controlled through members involvement in farmer groups because of their essential values, namely mutual respect, mutual support, and sharing. Understanding each Jabres cattle farmers motives and goals to become a group member is important in strengthening the Jabres cattle farmers group's dynamics. Success in understanding farmers' motives can provide critical information for making decisions regarding the strengthening and direction of farmer group development. Farmers motives to raise livestock are classified into three: economic motives, social motives, utilization of resources (Guntoro et al., 2016). Individuals want to join groups due to several goals, including selfdevelopment, social service, social enthusiasm, self-satisfaction and social, and emotional support (Baber et al., 2017).

Various systematic efforts are continuously made to understand and manage the farmers motives to encourage collective efforts realizing the group goals. Understanding farmers motives to join the Jabres cattle farmers group would provide important information to strengthen member roles in realizing group goals. It will also be able to become an entry point in improving group dynamics so that the development of Jabres cattle farms runs better and productively. Therefore, this study aims to identify Jabres cattle farmers motives to join the group and analyze the influencing factors on cattle farmers different motives in joining the farmers' group.

\section{Materials and Methods}

A survey was conducted to 119 Jabres cattle farmers in Brebes Regency, the current 
members of eight farmer groups categorized in the intermediate class. The respondents were selected using a multistage sampling method which is a probabilistic sampling technique carried out in stages. The purpose of using multistage sampling is to select respondents in areas that are concentrated in a limited geographic area (Taherdoost, 2018). The first stage, choosing five sub-districts purposively, was clustered as the center of Jabres cattle production, namely Ketanggungan, Bantarkawung, Banjarharjo, Larangan, Salem districts. The second stage randomly selected $20 \%$ of total farmers in each of eight groups of Jabres cattle farmers from five sub-districts. The last stage selected $50 \%$ of total members in each farmer group as the respondents.

The primary data were collected through interviews with farmers using a structured questionnaire. Furthermore, the data were analyzed using descriptive statistics to identify the motives and characteristics of farmers joining the Jabres cattle farmers group. The farmers motives are the reasons for doing something (Richter et al., 2021). In this study, understanding the reasons of farmers to join the farmer group were regarded useful information to formulate group development strategies. In the questionnaire, farmers were to choose several statements that represent their reasons to join the farmer group. Discriminant analysis analyzed the influencing factors to different motives of Jabres cattle farmers to join the Jabres cattle farmers group.

\section{Results and Discussion}

Table 1. Characteristics of Jabres cattle farmers

\begin{tabular}{lcc}
\hline Variables & Mean & Standard of Deviation \\
\hline Age of farmers (years) & 50.80 & 8.29 \\
Education attainment of farmers (years) & 7.23 & 4.12 \\
Farming experience (years) & 8.14 & 3.33 \\
Number of family members (heads) & 21.13 & 10.64 \\
Number of cattle owned (heads) & 3.87 & 1.21 \\
\hline
\end{tabular}

\section{Cattle Farmers Characteristics}

The description of Jabres cattle farmers' characteristics include age, education, farming experience, family size, and total cows owned by farmers. These social demographic conditions provide critical information for building more effective smallholder farms. The average age of Jabres cattle farmers is $\mathbf{5 0 . 0 8}$ years and is included in the productive category with sufficient physical and mental conditions. At the productive age, Jabres cattle farmers still have the physical strength to carry out the stages of farming activities, including looking for grass, cleaning stables, maintaining livestock health, and selling livestock. However, Jabres cattle farmers still have formal knowledge and education, which is categorized as low, namely elementary school graduates with an average length of 7.23 years. Less than optimal education can hinder the transformation of farmers towards commercialization and household has a positive influence on the possibility of improving farmer household education (Andaleeb et al., 2019). Older farmers tend to have less education, so they need to be given more training to increase their farming knowledge and skills (Harizanova-metodieva, 2014).

In general, the characteristics of farmers should receive attention to improve the performance of agricultural businesses. Farmers' age, farmers' experience, and farmers' education can be important elements for increasing business planning, production implementation, cost control, production entrepreneurship. Farmers' education as head of 
evaluation, and decision making in business development. Decision-making in business development is carried out to respond to external challenges so that farmers' positive characteristics are needed (Wilson, 2014).

\section{Motives of Farmers Joining Group}

A motive is something in a person/inner state that guides them to pursue specific goals and results. Every farmer has different expectations for actions and decisions they take, and this triggers motives. Individuals want to join social groups for self-development, social enthusiasm, self-satisfaction, and emotional support. Furthermore, based on this motive, humans can be grouped into individuals who want to learn/develop themselves, individuals who wish to socialize/interact, and capitalist/economicoriented (Baber et al., 2017).

Based on Table 2, most Jabres cattle farmers in the Brebes Regency (75.6 percent) joining the farmers' group due to the expectancy to have more interactions with other farmers. The second group is joining the group because they want to benefit from the local government's assistance and grants. The third group, selfenthusiasm, as a member, was a motive of cattle farmers to join the farmers' group. However, very few farmers get in touch with farmers' groups due to developing knowledge and skills.

Social motives are a person's inner condition that drives people's thoughts, feelings, and behavior in interactions with others. The social motive of Jabres cattle farmers is shown by joining the farmer group to get acquainted with many farmer friends. Interaction with fellow farmers is believed to enable to cover the shortcomings of each farmer. Having more farmer friends is expected to solve social, technical, and economic problems. Social motives can affect the ease of solving problems, reduce conflict tension in negotiations, and increase mutual benefits (De Dreu et al., 2000). Besides, farmers as human beings have a strong motive to build a close relationship and other people's support at a time of stress (Holmes, 2000; Horowitz et al., 2006). The Jabres cattle development area is a rural area that is still very related to an atmosphere of social interaction, a high sense of caring, and communicating with each other to get information. Such community character causes farmers to need a group of Jabres cattle farmers as a forum for interaction and communication.

As mentioned in Table 2, most of the cattle farmers (75.6 percent) joined the Jabres cattle farmer group, with the main reason to get a sense of security because they have many farmer friends. Farmers who join farmer groups intend to get a sense of security because they have many friends with low education (elementary school graduates) and have relatively more cattle than farmers who have other motives in joining as members.

The second category is farmers who join cattle farmer groups to obtain livestock assistance from the government. Based on Table 3 , economic reasons are mostly proposed by farmers with relatively low education (elementary school graduates).

Table 2. Motives of farmers joining group

\begin{tabular}{lcc}
\hline Motives & Number & Percentage \\
\hline Get status as a member & 8 & 6.7 \\
The sense of security because having many friends & 90 & 75.6 \\
Realizing personal business goals & 3 & 2.5 \\
Building self-pride & 1 & 0.8 \\
Getting government assistance & 16 & 13.4 \\
Increasing knowledge and skills & 1 & 0.8 \\
\hline Total & 119 & 100 \\
\hline
\end{tabular}


Table 3. Farmers' characteristics based on motives joining group

\begin{tabular}{lccccc}
\hline Motives & Age & Ed & Ex & NFM & NCO \\
\hline Get status as a member & 46.12 & 9.37 & 19.00 & 3.87 & 4.62 \\
Have the sense of security due to having many friends & 51.21 & 7.03 & 21.20 & 3.90 & 5.40 \\
Realize personal business goals & 41.33 & 12.00 & 16.66 & 4.00 & 3.33 \\
Build self-pride & 55.00 & 9.00 & 30.00 & 5.00 & 3.00 \\
Get government assistance & 52.62 & 6.00 & 22.18 & 3.56 & 3.43 \\
Increase knowledge and skills & 47.00 & 12.00 & 20.00 & 5.00 & 2.00
\end{tabular}

Notes: Age: Age of farmers; Ed: Education attainment; Ex: Farming experience; NFM: Number of family members; NCO: Number of cattle owned

Education is an important factor that provides a different picture of the six main reasons a farmer joins a farmer group. Meanwhile, farmers who have a higher education (high school graduates) tend to join farmer groups to improve knowledge and realize their beef cattle business goals.

The farmer's motives will be able to direct the actions taken by the farmers in the group. Farmers with a higher formal education are more likely to participate in the farmer groups (Alimirzaei and Asady, 2011) and tend to seek knowledge (knowledge-seeking farmers). They join farmer groups and confidently interact with extension workers and other knowledge sources to increase their understanding of raising beef cattle. Farmers with high education aim to be more competent in the livestock business so that this group of breeders continues to make efforts and approaches to develop production competence (Vik and Stræte, 2017).

\section{Factors influencing Jabres cattle farmers' different motives in joining the farmers' group}

Jabres cattle farmers have heterogeneous orientations and motives in joining the farmers' group. Understanding the farmer's motives can help formulate strategies and steps to serve members and strengthen farmer group institutions. Identifying farmer motives for joining groups can help develop specific services and activities to meet group members' needs.

Based on Table 4, farmers' education is an important factor that makes differences in their motives to join farmer groups $(P<0.05)$. The discriminant analysis illustrated that farmers with low education tend to join farmer groups with social motive. They enter farmer groups to get more social relations and economic assistance from the government. Meanwhile, farmers with higher education tend to join the farmer group to gain additional knowledge and realize beef cattle business goals (profitability and marketing), which they cannot get if they are not members.

Table 4. Discriminant analysis of factors influencing Jabres cattle farmers' different motives in joining the farmers' group

\begin{tabular}{lcccc}
\hline \multicolumn{1}{c}{ Variables } & $\begin{array}{c}\text { Wilks' } \\
\text { Lambda }\end{array}$ & $\begin{array}{c}\text { Standardized canonical } \\
\text { discriminant function } \\
\text { coefficients }\end{array}$ & F & $\begin{array}{c}\text { Significance } \\
\text { (p) }\end{array}$ \\
\hline Age of farmers (years) & 0.935 & -0.101 & 1.625 & .159 \\
$\begin{array}{l}\text { Education attainment of farmers } \\
\text { (years) }\end{array}$ & 0.932 & 0.148 & 1.941 & $.043^{*}$ \\
Farming experience (years) & 0.986 & 0.044 & .333 & .892 \\
$\begin{array}{l}\text { Number of family members } \\
\text { (heads) }\end{array}$ & 0.983 & 0.014 & .562 & .729 \\
$\begin{array}{l}\text { Number of cattle owned (heads) } \\
\text { (Constant) }\end{array}$ & 0.962 & 0.023 & 1.004 & .729 \\
\hline
\end{tabular}


Based on the discriminant analysis, the discriminant function equation is $D=2.976$ 0.101 (age of farmers) +0.148 (education of farmers) +0.044 (farming experience) +0.014 (number of family members) +0.023 (number of cattle owned).The discriminant function equation explains 59.1 percent of the variance of the farmer's motive to join the farmer group.

Farmers with a higher formal education make farmer groups not just a medium to gather and interact but can become groups that have a role in increasing members' knowledge and skills. The assumption that farmer groups are formed only to obtain government assistance should immediately be removed and replaced with a more strategic role for farmer groups, namely empowering the members by increasing their knowledge and skills. Farmer groups must be able to increase their role in increasing production, collaboration, and expanding markets to improve farmer families' welfare (Rahmadanih et al., 2018). Farmers with higher education will be more interested in joining and staying in groups for a long time if their needs for knowledge and business access can be met (Tolno et al., 2015).

\section{Conclusions}

Strengthening farmer institutions such as Jabres cattle farmers group in rural areas of Brebes Regency is a strategic effort to encourage an increase in beef cattle population. The majority of Jabres cattle farmers join farmer groups are driven by social motives, namely feeling secure to interact with other farmers and get help/assistance from the government. Meanwhile, a small number of farmers with higher education levels join the farmers' group to gain knowledge and skills and achieve the beef cattle business's business objectives, i.e., business profits. Among the farmers' characteristics, education background is a determining factor for different motives to join farmer groups.

\section{References}

Abdullah, A, M Jamila, A Amidah, A Aslina, and S Nurlaelah. 2019. The role of farmer group on development of beef cattle business. IOP Conf. Ser. Earth Environ. Sci. 247. doi:10.1088/17551315/247/1/012040.

Alimirzaei, E, and A Asady. 2011. Individual factors affecting farmers' motivation to participate in date growers' organizations in Khuzestan. Res. J. Appl. Sci. Eng. Technol. 3:725-730.

Andaleeb, N, M Khan, SA Shah, and R Ullah. 2019. Determinants of livestock farm household's welfare with main focus on women's involvement in livestock production in rural areas of District Mardan Khyber Pakhtunkhwa, Pakistan. Sarhad J. Agric. 35:43-47. doi:10.17582/journal.sja/2019/35.1.43.47.

Baber, R, Y Upadhyay, and RPS Kaurav. 2017. Individuals' Motivation for Joining a Social Group: Examining Their Homogeneity. Asia-Pacific J. Manag. Res. Innov. 13:43-51. doi:10.1177/2319510x18760616.

Bettencourt, EMV, M Tilman, V Narciso, ML da Silva Carvalho, and PD de Sousa Henriques. 2015. The livestock roles in the wellbeing of rural communities of Timor-Leste. Rev. Econ. e Sociol. Rural. 53:S063-S080. doi:10.1590/123456781806-94790053s01005.

De Dreu, CKW, LR Weingart, and S Kwon. 2000. Influence of social motives on integrative negotiation: A meta-analytic review and test of two theories. J. Pers. Soc. Psychol. 78:889-905. doi:10.1037/0022-3514.78.5.889.

Guntoro, B, YY Suranindyah, AA Suryanto, and Y Opatpatanakit. 2016. Farmers' Motives in Raising Ettawa Crossbred Goat in Yogyakarta, Indonesia. Int. Bus. Manag. 10:2706-2712.

Hansson, H, R Ferguson, C Olofsson, and L RantamäkiLahtinen. 2013. Farmers' motives for diversifying their farm business - The influence of family. J. Rural Stud. 32:240-250. doi:10.1016/j.jrurstud.2013.07.002.

Harizanova-metodieva, T. 2014. Dairy Business the Case of Bulgarian Dairy Cattle Farmers. Sci. Pap. Ser. Manag. 14:95-102.

Herrero, M, D Grace, J Njuki, N Johnson, D Enahoro, S Silvestri, and M C Rufino. 2013. The roles of livestock in developing countries. Animal. 7:3-18. doi:10.1017/S1751731112001954.

Hogg, MA, ZP Hohmann, and JE Rivera. 2009. Teaching and Learning Guide for: Why Do People Join Groups? Three Motivational Accounts from Social Psychology. Soc. Personal. Psychol. Compass. 3:111-117. doi:10.1111/j.17519004.2008.00157.x. 
Holmes, JG. 2000. Social relationships: The nature and function of relational schemas. Eur. J. Soc. Psychol. 30:447-495. doi:10.1002/10990992(200007/08)30:4<447::AIDEJSP10>3.0.CO;2-Q.

Horowitz, LM, KR Wilson, B Turan, P Zolotsev, MJ Constantino, L Henderson, LM Horowitz, KR Wilson, B Turan, P Zolotsev, MJ Constantino, and L Henderson. 2006. How Interpersonal Motives Clarify the Meaning of Interpersonal Behavior: A Revised Circumplex Model. Personal. Soc. Psychol. Rev. 10:67-86. doi:10.1207/s15327957pspr1001.

Rahmadanih, S Bulkis, M Arsyad, A Amrullah, and NM Viantika. 2018. Role of farmer group institutions in increasing farm production and household food security. IOP Conf. Ser. Earth Environ. Sci. 157. doi:10.1088/1755-1315/157/1/012062.

Richter, E, R Lazarides, and D Richter. 2021. Four reasons for becoming a teacher educator: A large-scale study on teacher educators ' motives and well-being. Teach. Teach. Educ. 103322. doi:10.1016/j.tate.2021.103322. Available from: https://doi.org/10.1016/j.tate.2021.103322

Taherdoost, H. 2018. Sampling Methods in Research Methodology; How to Choose a Sampling Technique for Research. SSRN Electron. J. doi:10.2139/ssrn.3205035.

Tolno, E, H Kobayashi, M Ichizen, M Esham, and BS Balde. 2015. Economic Analysis of the Role of Farmer Organizations in Enhancing Smallholder Potato Farmers' Income in Middle Guinea. J. Agric. Sci. 7:123-137. doi:10.5539/jas.v7n3p123.

Truong, L, Ho NN, Tran DT, and Nguyen XT. 2020. Does cattle production contribute to improving welfare of poor ethnic minority households in Central Vietnam. Livest. Res. Rural Dev. 32:161.

Vik, J, and EP Stræte. 2017. Embedded Competence: A Study of Farmers' Relation to Competence and Knowledge. Proc. Food Syst. Dyn. 0:392-403. doi:10.18461/pfsd.2017.1740.

Wilson, P. 2014. Farmer characteristics associated with improved and high farm business performance. Int. J. Agric. Manag. 3:1-9. doi:10.5836/ijam/2014-04-02. 